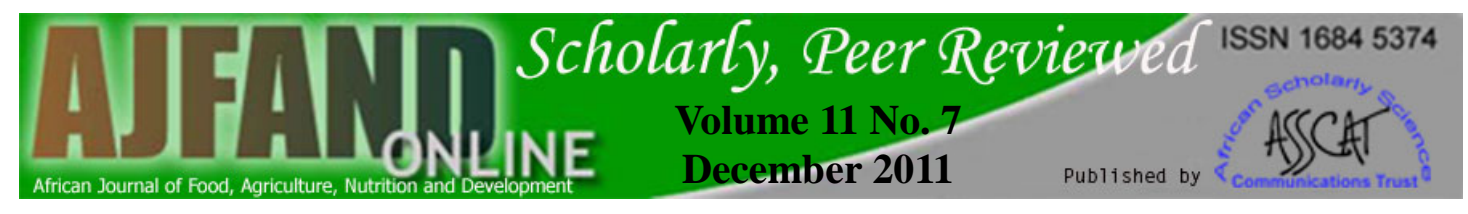

\title{
EFFECT OF Dermestes maculatus ON THE NUTRITIONAL QUALITIES OF TWO EDIBLE INSECTS (Oryctes boas AND Rhynchophorus phoenicis)
}

$$
\text { Fasunwon } \mathrm{BT}^{1^{*}} \text {, Banjo } \mathrm{AD}^{2} \text { and } \mathrm{TA} \text { Jemine }{ }^{3}
$$

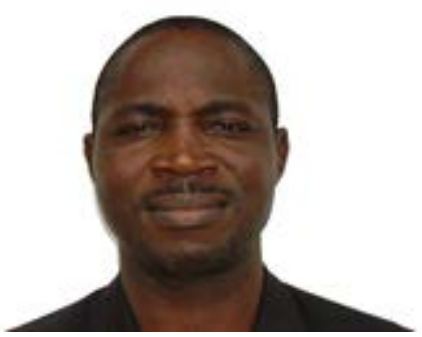

Fasunwon BT

*Corresponding author email: 머ddysoore@yahoo.com

${ }^{1} \&^{3}$ Tai Solarin University of Education, Ijagun, Ogun State, Nigeria

${ }^{2}$ Olabisi Onabanjo University, Ago Iwoye, Ogun State, Nigeria 


\section{ABSTRACT}

This study aimed to assess the effect on nutritional composition of two 'Edible Insects' (Larva of Oryctes boas and Rhynchophorus phoenicis) after infestation by Dermestes maculatus. The study was done over a period of six weeks by subjecting these edible insects to different conditions of storage (using pepper and salt). The assessment was based on weight and proximate analysis differences before and after infestation under these media of storage. The larva of Oryctes boas in the container with salt as preservative had the least weight loss (from $30.00 \pm .0000 \rightarrow 39.70 \pm$ $.3000 \rightarrow 36.30 \pm 1.000$ ), followed by the container with pepper as preservative (from $30.00 \pm .0000 \rightarrow 31.05 \pm 5.000 \rightarrow 25.25 \pm .1500$ ) while the highest weight loss occurred in the container without preservative constituents (from $30.00 \pm .0000 \rightarrow$ $30.30 \pm 1.000 \rightarrow 21.15 \pm 5.000$ ). Likewise, the larva of Rhynchoporus phoenicis in the container with salt as preservative constituent had the least weight difference of $(16.00 \pm .0000 \rightarrow 20.80 \pm .0000 \rightarrow 13.65 \pm .1500)$; followed by the container with pepper as preservative (from $16.00 \pm .0000 \rightarrow 16.40 \pm 1.000 \rightarrow 6.700 \pm .2000$ ), while the highest weight loss occurred in the container without preservative (from $16.00 \pm$ $.0000 \rightarrow 7.850 \pm 5.000 \rightarrow 6.300 \pm .0000$ ). The mortality rate of Dermestes maculatus was also determined, showing that the larva of Oryctes boas and Rhynchophorus phoenicis containing salt as preservative had the highest mortality rate of $60 \%$ and $80 \%$, respectively, followed by that containing pepper as preservative having $20 \%$ and 30\% respectively, and that containing no preservative constituent had no mortality rate. It was concluded that, Dermestes maculatus' infestations on the larva of edible insects showed a difference in the proximate analysis of these edible insects before and after infestation. Therefore, it was suggested that edible insects should be well dried and locally preserved with salt and pepper.

Key words: Dermestes maculatus, Rhynchoporus phoenicis, Oryctes boas, proximate, mortality 


\section{INTRODUCTION}

Over the past decades, recognition by people of the effects of Dermestes maculatus on the role of nutritional value of stored product in food security has grown considerably. Several investigations have shown that in addition to insects' fundamental contributions to pollen dissemination, insects contribute significantly to livelihoods in both rural and urban areas [1]. Insects are popular food in many cultures all over the world as an occasional delicacy or a replacement food in times of shortages as in droughts, floods or war. The potential of insects need to be more seriously considered in Food Security and Poverty Alleviation Strategies in subSaharan Africa [2]. Insects have played an important role in the history of human nutrition in Africa, Asia and Latin American. Some of the most important groups of the hundreds of insect species that have been used as human food include: Grasshoppers, Rhinoceros beetles, Caterpillars, Termites, Bees, Wasps, and Broods (larvae and pupae) as well as winged ants, cicadas and a variety of aquatic insects, which insects have a high population in the tropics [3].

The problems with utilizing insects' proteins are the lack of social acceptance, nutritional knowledge, information and disbelief about delicacies of these insects that are naturally abundant in our farms and forests. There is need for insect eaters to educate the public about the value of edible insects. Despite these problems that pose challenges to insect Cultivators and Gatherers, it is also noticed and confirmed that Dermestes maculatus (Hide beetle), regarded as pests of stored food products, feed on dead insects. Hide beetle has recently been a pest in poultry houses where huge populations of matured larvae have damaged wooden structural materials as reported by Josland [4] in the UK and USA.

Dermestes maculatus is widely recognized as a cosmopolitan pest of stored commodities especially those containing animal proteins. The Hide beetle feeds on hides, skins, feathers and horns; and is a known pest of dried fish [5]. These are groups of small beetles whose larvae are especially injurious to dried meat, wool, fur and other animal materials [6]. Dermestes's occurrence in a range of stored products in various countries had been reviewed in relation to its general biology and infestation of dried fish in Nigeria, by investigating the effects of regulated salt treatment of fish on the developmental biology of the beetle when reared in diets under two sets of conditions of temperature and humidity [7, 8].

Development of Dermestes maculatus is not possible at $40^{\circ} \mathrm{C}$ or above, because, temperature above $40^{\circ} \mathrm{C}$ can kill or repel all these beetles. Such temperature can disinfect fish or delay invasion by Dermestes maculatus as long as it is achieved throughout the batch. If some of the fish remains at normal temperatures, the beetle will migrate. Well-dried fish reduces the rate of Dermestes population growth.

Salting of fish gives protection against Dermestes maculates, partly because larval development is prolonged and larval mortality increases with increase in salt content. In experiments at $30^{\circ} \mathrm{C}$, larval development took 37 days on fish with $3.5 \%$ salt content compared with $21 \frac{1}{2}$ days on unsalted fish and mortality reached $100 \%$ when the salt content was increased to $9.2 \%$ by brining for $1 \frac{1}{2} \mathrm{~h}$ [7]. This susceptibility to 
salt may explain the less frequent occurrence of Dermestes maculatus in cured marine fish, as salt is more commonly used in marine fish processing. Dermestes ater is also adversely affected by salting, by contrast, Dermestes frischii is relatively tolerant of salt, at $30^{\circ} \mathrm{C}$ and $75 \% \mathrm{RH}$, the total developmental period increased only to $42-53$ days instead of the 34 days on unsalted fish meal. Developments of these pests were prevented when the salt contents were $14 \%$ and $25 \%$, respectively [9].

Insects, fish and meat play the same role in the human body. As food, caterpillars are regulars in the village but meat is rare [10], being that these insects are readily available as food and less expensive to procure compared to meat. Many people in Tropical Africa collect edible insects as food. The habit is especially well developed among the Cultivators of the forest regions. It is uncertain whether these insects are eaten because of their nutritional qualities or due to their cultural heritage or folktales. The aversion to insects as human food among Europeans is nothing more than custom and prejudice [11]. Grubs(beetles) of the palm weevil, Rhynchophorus phoenicis Fabri (Coleoptera curculionidae) and Analeptes trifasciata (Coleoptera: Scarabaeidae) are fried and eaten in several parts of Western Nigeria, in Delta, Edo and Bayelsa States where active marketing of these insects takes place. The people in the river-rine areas of Ondo State: (Bolowou, Opuba, Ajapa, Apata and all other people in towns of Arogbo Kingdom) do eat these insects when fried, roasted and even in the raw form.

Edible insects like caterpillars and grubs are important sources of protein and should be considered an alternative in efforts to increase food security in central African countries. Caterpillars are already an important food intake for many in central Africa; about $85 \%$ of participants in a survey in the Central African Republic consume caterpillars, $70 \%$ in the Democratic Republic of Congo and $91 \%$ in Botswana [8].

Edible insects like Rhynchophorus phoenicis (Coleoptera curculionidae) and Analeptes trifasciata (Coleoptera scarabaeidae), snout beetle and Rhinoceros beetle, respectively are species that damage palms. The former is a major secondary pest of Raphia (Raphia hookeri Mamwendland) and young oil palm (Elaesis gunineensis Jacq) which are abundant in the palm belt of the Niger Delta wetland which has suitable environmental conditions for its growth. Rhynchophorus phoenicis normally invades these palms after they have been damaged by Rhinoceros beetle (larvae) or by humans during tapping for wine and other insects. The larval stages of these insects, which are big with fleshy bodies, are highly nutritious and cherished as traditional delicacies by the indigenes of all the ethnic tribes in the Niger Delta (Ijaw, Urhobo, Ikwerre), Igbo and Yoruba in Nigeria, as well as other countries like Angola, Columbia, India, Cameroon and France [12].

The nutritional potentials of both Rhynchophorus Phoenicis and Analeptes trifasicata has not been tapped accordingly in the tropical world. People still use the crude traditional methods of farming and harvesting this valuable insect due to lack of modern implements for its harvest. For instance, the Bari and Indians use only the Jessenia palms as "grub farms" by cutting them down as logs for Rhynchophorus 
infestation [13]. The Columbians also cut down palm trees deliberately to provide fodder for these insects, while in Nigeria people cut down oil and Raphia palm trees to be infested by Oryctes boas or Rhynchophorus phoenicis. The palm weevils are highly valued as human food by people of Manipur state of North Eastern India, who see insects as the cheapest sources of animal protein [14].

Caterpillar has been used as a protein supplement in poultry and cattle feeds. It contains $38+\%$ proteins, $16+\%$ fats, $13+\%$ carbohydrates and some chitin [15]. The lipids are made up of C16 and C18 saturated fatty acids and C18:1 and C18:2 saturated fatty acid. It has been estimated that 100 grams of it may provide $76 \%$ of an average human daily protein requirements and $100 \%$ of the daily requirements of vital vitamins and minerals which makes it compare favourably with meat and fish in terms of protein, fat, vitamins and calorific content [15].

To this effect, it has become pertinent to investigate the infestation effect of Dermestes maculatus on the nutritional composition of two selected edible insects Oryctes boas and Rhynchophorus phoenics larvae, commonly known as Rhinocerous beetle larvae and Snout beetle larvae, respectively, having been observed to be a major source of protein like fish and other animal meat.

\section{MATERIALS AND METHODS}

\section{Collection of samples}

Two different samples of insects were collected. These were: the larvae of Rhynchophorus phoenicis and Oryctes boas) and the sample of Dermestes maculatus (Hide beetle). The samples were collected from different locations in Ondo and Lagos States in the South Western part of Nigeria. The larvae of Oryctes boas were collected at Bolowou, Ese-Odo Local Government Area in Ondo State; the larva of Rhynchophorus phoenicis were collected at Itokin in Lagos State and samples of Dermestes maculatus were collected from Igbokoda(fish market), area of Ondo State.

\section{Sorting and identification}

The selected larvae of edible insects and Dermestes maculatus were collected and sorted for proper identification in the Laboratory of Entomology Department, Olabisi Onabanjo University, Ago-Iwoye of Ogun State.

\section{Processing and preservation}

The two samples collected were processed and preserved as follows:-

The larvae of Oryctes boas were washed with clean water, posterior end cut open to remove faecal waste and boiled for ten (10) minutes. The water was sieved again and the sample boiled for another fifteen (15) minutes and then sun-dried for twenty-one (21) days from 10 am to 4 pm daily. While the larvae of Rhynchophorus phoenicis were only washed with clean water without removing the intestines and parboiled for ten (10) minutes. The water was sieved and the sample boiled on a stove for another fifteen (15) minutes and then sun-dried for twenty-one (21) days from 10a.m to 4p.m daily. 
The Dermestes maculatus (hide beetles) were picked with a soft (moist) camel hair brush and kept in a plastic jar (Container) along with little fish meal and covered with fine netting and placed in a waterbath for preservation by disallowing invasion of thief ants on the fish meal.

The processed and preserved edible insects were prepared in 30grams of three replicates for each sample; the insects were grounded separately for proximate and mineral analysis at the Nigerian Institute of Science Laboratory Technology (NISLT), Samonda in Ibadan (Oyo State). The samples were analyzed chemically according to the official methods of analysis recommended by the Association of Official and Analytical Chemists [16]. .

The larvae of Rhinoceros beetle were labeled with $\mathrm{X}_{1} \mathrm{X}_{2}, \mathrm{Y}_{1} \mathrm{Y}_{2}$ and $\mathrm{Z}_{1} \mathrm{Z}_{2}$, while the Rhynchophorus phoenics was labeled with $\mathrm{A}_{1} \mathrm{~A}_{2}, \mathrm{~B}_{1} \mathrm{~B}_{2}$ and $\mathrm{C}_{1} \mathrm{C}_{2}$ to show the three (3) experiments in three replicates, respectively.

\section{Method of infestation}

In each of the set up replicates, twenty (20) Dermestes maculatus and thirty (30) grams of Oryctes boas were introduced into each container, respectively. Ten (10) grams of salt was also introduced into the replicates of $X_{1} X_{2}$ and that of $Y_{1} Y_{2}$ replicates was also ten grams of dried pepper, and that of replicates $Z_{1} Z_{2}$ container contained Dermestes maculatus and Oryctes boas, likewise for Rhynchophorus phoeniicis, labelled $\mathrm{A}_{1} \mathrm{~A}_{2}, \mathrm{~B}_{1} \mathrm{~B}_{2}$ and $\mathrm{C}_{1} \mathrm{C}_{2}$.

\section{Determining rate of infestation}

Before the experiment commenced, the edible insects were weighed, then subjected to Dermestes maculatus for infestation. After the first two weeks, the insects were weighed again to access or determine the manifestation of depreciation or loss in weight. The weighing was done at two (2) weeks' intervals.

At the end of the experiment in six (6) weeks, the sample were weighed at four different times and these infested edible insects by Dermestes maculatus were grounded in each pair of container in replicates and subjected to proximate analysis and mineral composition analysis.

\section{Mortality rate of Dermestes maculatus}

The mortality rate was taken every two (2) weeks for four different times till the end of the experiment using the equation below: $\mathrm{X}(\%)=(\mathrm{Nt} / \mathrm{No}) \times 100$

Where: No: Initial nos of Dermestes

Nt: Final nos of Dermestes

\section{RESULTS}

The results in Figures $1 \& 2$ showed that there was considerable decrease in the weight values of these insects as the weeks passed by under the infestation of Dermestes maculatus. At the first assessment (2nd week) of infestation, larvae of 
Oryctes boas $\mathrm{X}_{1} \mathrm{X}_{2}$ had the highest increase in weight of $39.70+.3000$, followed by $\mathrm{Y}_{1} \mathrm{Y}_{2}$ 31.05+.50 and $\mathrm{Z}_{1} \mathrm{Z}_{2}$ had the least value of $30.30+1.00$, while Rhynchophorus phoenicis $\mathrm{A}_{1} \mathrm{~A}_{2}$ had a weight increase of $34.80+.00$, followed by that of $\mathrm{B}_{1} \mathrm{~B}_{2}$ with $30.40+1.00$ and $\mathrm{C}_{1} \mathrm{C}_{2}$ with 21.85+5.00. In the second assessment (i.e. 4th week) $\mathrm{X}_{1} \mathrm{X}_{2}$ had a weight values of $38.80+.20$, followed by $\mathrm{Y}_{1} \mathrm{Y}_{2}$ with $30.65+5.00$ and $\mathrm{Z}_{1} \mathrm{Z}_{2}$ with $21.58+.25$, while $\mathrm{A}_{1} \mathrm{~A}_{2}$ had $31.30+.40$, followed by $\mathrm{B}_{1} \mathrm{~B}_{2} 28.40+.10$ and $\mathrm{C}_{1} \mathrm{C}_{2}$ had $21.15+5.00$. In the third assessment (. 6th week); $X_{1} X_{2}$ had weight decrease of $36.30+1.00$, followed by $\mathrm{Y}_{1} \mathrm{Y}_{2}$ weight value of $25.25+.15$ and $\mathrm{Z}_{1} \mathrm{Z}_{2}$ with $21.15+$ 5.00 while, $\mathrm{A}_{1} \mathrm{~A}_{2}$ had a weight decrease of $23.25+.15$, followed by $\mathrm{B}_{1} \mathrm{~B}_{2}$ with $20.70+.20$ and $C_{1} C_{2}$ had the least value of $20.30+.00$.

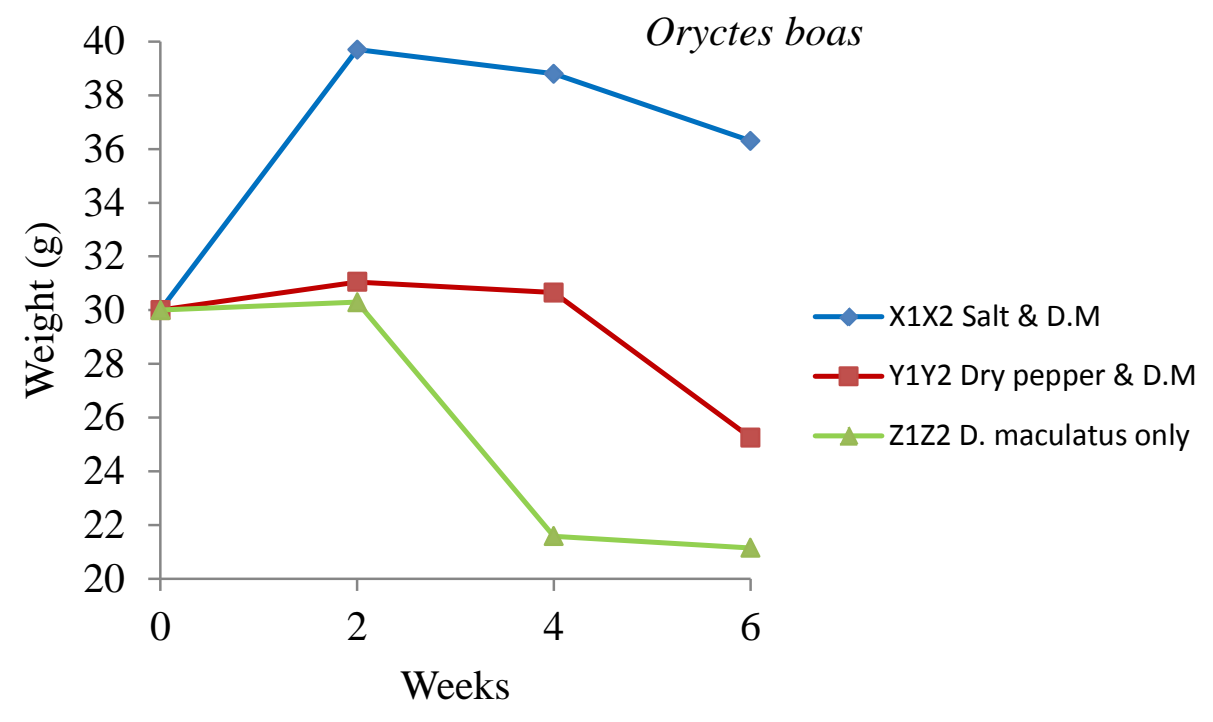

Figure 1: Weight changes of infested Oryctes boas (Larvae) by Dermestes maculatus. 


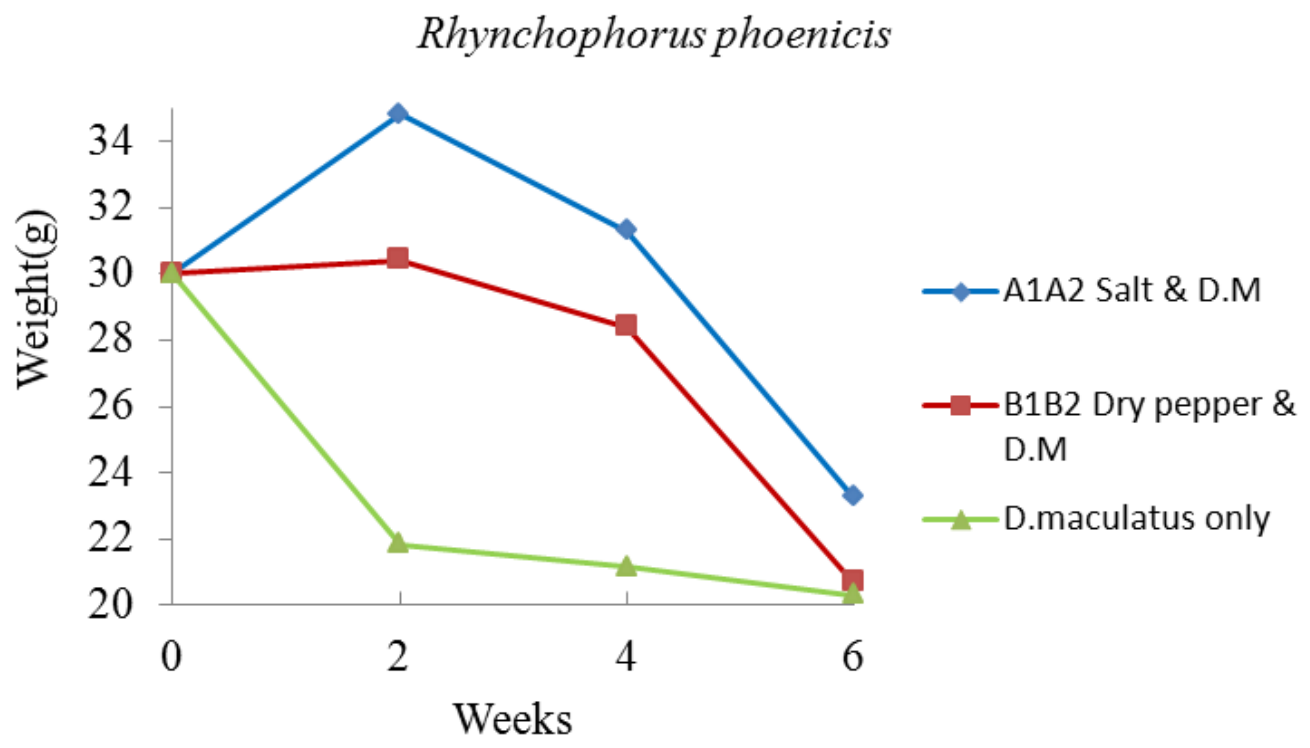

Figure 2: Weight changes of infested Rhynchophorus phoenicis (Larvae) by Dermestes maculatus.

\section{Effect on nutritional composition}

In Tables 1 \& 2, the proximate analysis and mineral composition of the two edible insects' larvae before infestation were shown respectively. However, there were significant difference in the values obtained compared to those earlier reported by Banjo et al. [3] and Thomas [14] possibly due to time and area of collections. The aftermath of the susceptibility of these edible insects were indicated in Table 3 as regards their proximate values after the infestation. The ash, fat, and fiber contents of these edible insects were significantly affected under the presence of the two mainly used preservatives (salt and dry pepper), with a proportional increase in their protein contents as stated by Banjo et al. [3] and Thomas [14] that their dry matter shows significant increase in protein contents.

\section{Mortality rate}

The result in Table 4 shows the mortality rate of Dermestes maculatus in the experiment under an average temperature of $30^{\circ} \mathrm{C}$. The highest death rate occurred in the salt container's larva of Rhynchophorus phoenicis $\mathrm{A}_{1} \mathrm{~A}_{2}$ been higher than that of Oryctes boas $\mathrm{X}_{1} \mathrm{X}_{2}$ due to the high contents of fat contained in the larva of Rhynchophorus phoenicis. 


\section{DISCUSSION}

The precautions taken in this study were to enhance proper drying of the collected insects for good storage and assess their susceptibility to storage pests. It was noted that the protein contents of $Z_{1} Z_{2}$ and $C_{1} C_{2}$, which had no preservatives added to it, showed a decrease which could naturally had been due to the infestation of Dermestes maculatus on the edible insects. Although it was more evident in that there was preference of infestation on the larvae of Oryctes boas than that of the Rhynchophorus phoenics, due to higher content of protein in the latter.

The rate of decrease or depreciation in weight occurred more between the Fourth and Sixth (4th - 6th) weeks due to the fact that at Zero (initial) week to the Second week (0th - 2nd week) the concentration of the preservative constituents of salt and pepper were high and strong, thus, inhibiting the action of Dermestes maculatus, Thus, as the time progresses the concentration of the preservative constituents (salt and pepper) became lower and weaker, this gave room for Dermestes maculatus to become more active and effective in its infestation on the larvae. Therefore, between the two preservative constituents (salt and pepper), the infestation of Dermestes maculatus on the containers of $Y_{1} Y_{2}$ and $B_{1} B_{2}$ respectively were very significant than the containers of $\mathrm{X}_{1} \mathrm{X}_{2}$ and $\mathrm{A}_{1} \mathrm{~A}_{2}$ respectively. This was due to the preservative potential of salt compared to that of dry pepper.

In Comparing the larvae of Oryctes boas and Rhynchophorus phoenicis based on the depreciation or loss of weight due to infestation of Dermestes maculatus, the decrease or loss in weight occurred majorly on the larvae of Rhynchophorus phoenicis because they were not well dried due to the high content of fat. This enhanced Dermestes maculatus to become more active and infests more on the larvae of Rhynchophorus phoenicis. Dermestes maculatus infests on soft body materials than that of tough bodies. The larvae of Oryctes boas were well dried thus reduces the rate of infestation of Dermestes maculates. This correlates with the report of Osuji [7] that well dried fish reduces the rate of Dermestes infestations.

The highest death rate was recorded in the containers of the preservative constituent of salt followed by that of dry pepper. However, death rate was not recorded in the containers without preservatives constituents. This study showed that at Zero (initial) to sixth week in the container of preservative constituents of salt the mortality rate in the containers of Oryctes boas, $\mathrm{X}_{1} \mathrm{X}_{2}$ was $60 \%$; Rhynchophorus phoenicis $\mathrm{A}_{1} \mathrm{~A}_{2}$ was $85 \%$. In the container of dry pepper preservative; mortality rate of Oryctes boas $\mathrm{Y}_{1} \mathrm{Y}_{2}$ was $35 \%$; while the larvae of Rhynchophorus phoenicis $\mathrm{B}_{1} \mathrm{~B}_{2}$ was $30 \%$, and containers without preservative constituents; mortality rate was $10 \%$ in $\mathrm{Z}_{1} \mathrm{Z}_{2}$ and non in $\mathrm{C}_{1} \mathrm{C}_{2}$. The death rate occurred between the second weeks to the sixth week, thus, as the experiment progresses, the concentration and potentials of these preservative constituents became weaker and gradually ineffective, hence there was minimal mortality in the containers without the preservative constituents. This showed that Dermestes maculatus are parasites which can also infest on edible insects for survival as they occurred on fish. 
Consequently Osuji [7] stated, that salting of fish gives protection against Dermestes maculatus, partly not because larval development is prolonged but mainly because larval mortality increases with increasing salt content. In experiment at $30^{\mathrm{O}} \mathrm{C}$, larval development took 37 days on fish with $3.5 \%$ salt content compared with $21 \frac{1}{2}$ days on unsalted fish, and mortality reached $100 \%$ when salt content was increased to $9.2 \%$ by brining for $1 \frac{1}{2} \mathrm{~h}$ [7]. This susceptibility to salt may explain the less frequent occurrence of Dermestes maculatus in cured marine fish, as salt is more commonly used in marine fish processing as stated by FAO [8].

\section{CONCLUSION}

It has been shown that Dermestes maculatus which infests dry fish as stated by Osuji [7] could equally infests edible insects if not properly stored, thus the use of various constituents (salt and pepper) as preservative by rural people should be encouraged as it has been indicated that these pests actually devalue the proteins' content of these edible insects if not properly stored. Therefore, the study of edible insects as host to Dermestes maculatus and use of salt and dry pepper as preservative constituents against the incessant infestation of Dermestes maculatus would help in the sustainability of the required nutrients contained in edible insects for consumption by man and the commercial value of edible insects in encouraging insects-gatherers (traders).

The extent and value of quantitative losses caused to dried fish by Dermestes spp. have been assessed by various investigators and estimates range from negligible up to $50 \%$ weight loss, depending on length of storage, salt content, moisture content, climatic conditions and general hygiene during processing and storage. Weight losses due to fragmentation have also been investigated but the contribution of Dermestes spp. to this process has not been superlatively assessed. This study is highly significant in promoting proper harvesting, storage and utilization of our naturally given sources of food to reduce malnutrition and lack of essential nutrients in our diet especially in developing countries of Africa.

\section{ACKNOWLEDGEMENTS}

The authors hereby acknowledge and express our sincere gratitude to Olabisi Onabanjo University and Tai Solarin University of Education, Ijagun, Nigeria for providing the environment to carry out this research. 
Table 1: Proximate analysis of two selected edible insects

\begin{tabular}{|llllll|}
\hline Insect Sample & \%Protein & \%Ash & \%Moisture & \%Fat & \%Crude fiber \\
\hline Oryctes boas & 55.82 & 14.965 & 11.7 & 7.115 & 1.155 \\
Rhynchophorus & 28.01 & 7.72 & 23.5 & 18.905 & 1.085 \\
phoenicis & & & & & \\
\hline
\end{tabular}

*Proximate Analysis \% of two selected larva of edible insects

Table 2: Percentage mineral composition of two edible insects

\begin{tabular}{|lcccccccc|}
\hline Insect sample & $\% \mathrm{Ca}$ & $\% \mathrm{~K}$ & $\mathrm{PPMNa}$ & $\% \mathrm{Mg}$ & $\mathrm{PPMMn}$ & $\mathrm{PPCu}$ & $\mathrm{PPMZn}$ & PPMFe \\
\hline $\begin{array}{l}\text { Oryctes boas } \\
\begin{array}{l}\text { Rhynchophorus } \\
\text { phoenicis }\end{array}\end{array}$ & 1.32 & 0.195 & 72.095 & 0.45 & 30.4475 & 0.7925 & 4.1125 & 93.2045 \\
\hline
\end{tabular}

*Percentage Mineral Composition of Two Selected Larva of Edible Insects 
Table 3: Proximate analysis of infested larva of two edible insects subjected to Dermestes maculatus and preservative constituents

\begin{tabular}{|c|c|c|c|c|c|c|c|}
\hline Insect sample & $\begin{array}{l}\text { Replicate } \\
\text { (plastic } \\
\text { jar) }\end{array}$ & Constituents & $\begin{array}{l}\% \\
\text { Ash }\end{array}$ & $\begin{array}{l}\% \\
\text { Protein }\end{array}$ & $\begin{array}{l}\% \\
\text { Moisture }\end{array}$ & $\%$ Fat & $\begin{array}{l}\% \\
\text { Fiber }\end{array}$ \\
\hline \multirow[t]{3}{*}{ Oryctes boas } & $\mathrm{X}_{1} \mathrm{X}_{2}$ & Salt \& D.M & 9.38 & 60.5661 & 30.06 & 7.81 & 1.321 \\
\hline & $\mathrm{Y}_{1} \mathrm{Y}_{2}$ & $\begin{array}{l}\text { Pepper } \quad \& \\
\text { DM }\end{array}$ & 3.36 & 56.1273 & 28.45 & 4.26 & 0.761 \\
\hline & $\mathrm{Z}_{1} \mathrm{Z}_{2}$ & D.M only & 3.92 & 39.3392 & 14.43 & 4.52 & 0.812 \\
\hline \multirow[t]{3}{*}{$\begin{array}{l}\text { Rhynchophor } \\
\text { us } \\
\text { Phoenicis }\end{array}$} & $\mathrm{A}_{1} \mathrm{~A}_{2}$ & Salt \& Dm & 9.16 & 34.8127 & 34.79 & 20.07 & 1.221 \\
\hline & $\mathrm{B}_{1} \mathrm{~B}_{2}$ & $\begin{array}{l}\text { Pepper } \quad \& \\
\text { D.m }\end{array}$ & 4.08 & 37.3048 & 14.32 & 30.72 & 0.911 \\
\hline & $\mathrm{C}_{1} \mathrm{C}_{2}$ & D. M only & 5.45 & 22.6617 & 18.5 & 13.47 & 0.887 \\
\hline
\end{tabular}

Table 4: Mortality rate of Dermestes maculatus for the experiment

\begin{tabular}{|c|c|c|c|c|c|c|c|c|c|}
\hline Insect Sample & $\begin{array}{l}\text { Replicate } \\
\text { (plastic } \\
\text { jar) }\end{array}$ & Constituents & $\begin{array}{l}\text { No of } \\
\text { D.M } \\
\text { Introduced }\end{array}$ & $\begin{array}{l}\text { Zero } \\
\text { week }\end{array}$ & $\begin{array}{l}2^{\text {nd }} \\
\text { week }\end{array}$ & $\begin{array}{l}4^{\text {th }} \\
\text { week }\end{array}$ & $\begin{array}{l}6^{\text {th }} \\
\text { Week }\end{array}$ & $\begin{array}{l}\text { death } \\
\text { rate }\end{array}$ & $\begin{array}{l}\text { Survival } \\
\text { rate }\end{array}$ \\
\hline \multirow[t]{3}{*}{ Oryctes boas } & $\mathrm{X}_{1} \mathrm{X}_{2}$ & Salt & 20 & - & 8 & 2 & 2 & 60 & 40 \\
\hline & $\mathrm{Y}_{1} \mathrm{Y}_{2}$ & Pepper & 20 & - & 2 & 3 & 2 & 35 & 65 \\
\hline & $\mathrm{Z}_{1} \mathrm{Z}_{2}$ & - & 20 & - & - & 1 & 1 & 10 & 90 \\
\hline \multirow{3}{*}{$\begin{array}{l}\text { Rhynchophorus } \\
\text { phoenicis (larva) }\end{array}$} & $\mathrm{A}_{1} \mathrm{~A}_{2}$ & Salt & 20 & - & 10 & 3 & 4 & 85 & 15 \\
\hline & $\mathrm{B}_{1} \mathrm{~B}_{2}$ & Pepper & 20 & - & 3 & 2 & 1 & 30 & 70 \\
\hline & $\mathrm{C}_{1} \mathrm{C}_{2}$ & - & 20 & - & - & - & - & 0 & 100 \\
\hline
\end{tabular}




\section{REFERENCES}

1. Stack J, Dorward A, Gondo T, Frost P, Taylor F and N Kurebgaseka Mopane Worm Utilization and Rural Livelihoods in Southern Africa, CIFOR Livelihood Conference, Bonn. 2003.

2. $\quad$ Defoliart G R Insects as Human Food. Crop Protection (II). 1992; 5: 395399.

3. Banjo A D, Lawal O A and E A Songonuga The Nutritional value of fourteen species of edible insects in Southwestern Nigeria. Afr. J. of Biotechnology: 2006; 5 (3): 298-301.

4. Josland $\mathbf{P}$ Hide beetle: biology, damage and control: in poultry houses. AglinkF Wellington, Media Services, Ministry of Agriculture and Fisheries. 1978; 143.

5. Cohen E Fatty acid synthesis by the Hide beetle Dermestes maculatus (Dermestidae: Coleoptera) Ent. Exp \& appl. 1974; 17: 433-438.

6. World Book Dictionary. P. cm Millennium 1. (A-K) World Book, Inc. 2000; 96.

7. Osuji FNC The effects of salt treatment of fish on the developmental biology of Dermestes maculatus (Coleoptera, Dermestidae) and Necrobia rufipes (Cleridae). Entomol. Exp. Appl. 1975; 18: 472-479.

8. FAO. A field guide to the types of Insects and mites infesting cured fish, British Museum (Natural History). 2009.

9. Amos TG A field guide to the types of insects and mites infesting cured fish, British Museum (National History). 1968.

10. Muyay T Les insects' comme Alimente de l'Homme. Pubn.Ser 11, CEEB A. Bandundu, Zaire 1981; 69: 177.

11. Defoliart G R Insects as Human Food. Elsevier Science (Publishers), 1992b; 295-399.

12. Thomas $\mathbf{C} \mathbf{N}$ and BA Okwapkam Assessment of Nutrient Composition of Adults, pupae, larvae of Rhynchophorus phoenicis (Coleoptera:Curculinidae) in palms of Niger Delta. Niger Delta Biologia: 2006; 6 (2): 48-52.

13. Beckerman S The use of palms by the Bari Indians of the Maracaibo Basin. Principles. J. of the Palm Society: 1977; 21(4): 143-154. 


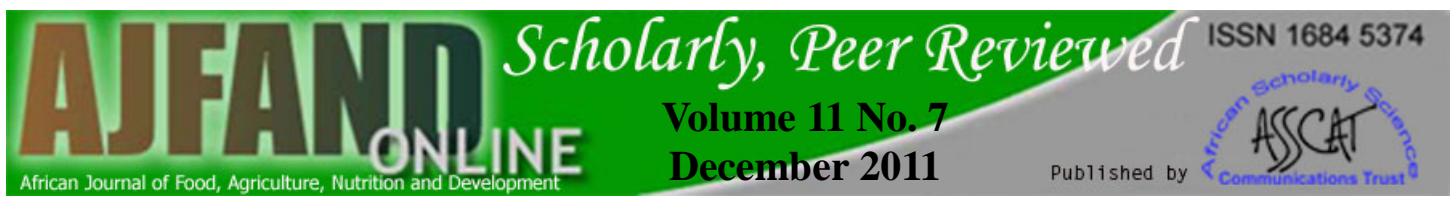

14. Thomas C N Biology, utilization and Rearing of, Rhynchophorus phoenicis (F) (Coleoptera: curriculionidae) in the Niger Delta Area of Nigeria Ph.D. Thesis, Rivers State University of Science and Technology, Nkpolu, Port Harcourt, Nigeria. 2003.

15. Allotey $\mathbf{J}$ and $\mathbf{S}$ Mpuchane Utilization of useful insects as Food Source. Afr. J of Food Agr. Nutr. And Dev. 2003; 3: 2.

16. AOAC. Association of Official and Analytical Chemists. $12^{\text {th }}$ Ed. Washington D.C., 1999. 